\title{
Measuring the potential power elite in the UK and Sweden
}

\author{
Dave Griffiths, Paul Lambert and Erik Bihagen
}

\begin{abstract}
This paper proposes a methodology for using survey data to understand the composition of elites, through analysing the pool of potential members. An occupational-based measure of 'potential power elite' is created and compared with other measures of occupational advantage. It is argued that this measure can be utilised to explore if the processes causing certain social groups to be under-represented in elite positions are around selection or the population recruited from. We provide analysis of elite positions in the UK and Sweden, demonstrating differences in terms of the potential pool of elite members and the occupational histories of people of those employed in roles associated with elite recruitment. We argue that understanding the composition of the potential power elite provides a more nuanced analysis of the processes of meritocracy in accessing positions of power and social influence.
\end{abstract}

Key words: Power elite; social stratification; social mobility; occupational attainment.

\section{Introduction}

The term 'elites' is often used inconsistently, with the classical sociological description referring to power and influence over a wider sector (e.g. Mosca 1939; Scott 2008). However, the term elites is often to refer to high performers (Ashley 2010; Larivière et al. 2010), the wealthy (Henry and Saunders 2012; Mason 2013) or as a social class (Bourdieu 1984; Savage et al. 2013). In recent years, influential powerbrokers are commonly portrayed as becoming more inclusive across many European countries (Ruostetsaari 2006; Griffiths et al. 2008; Heemskerk and Fennema 2009). Whilst this change is largely championed as a positive development, there is little explanation of why these changes have occurred. In this paper, we propose a method for assessing the representativeness of elites, using the classical sociological terminology, through a measure derivable from easily-available large-scale social surveys. This is used to provide a framework for understanding the mechanisms of elite recruitment and ascertaining why patterns of over-representation emerge.

\section{Understanding elites}

Classical theorists have examined how elites operate, as well as their recruitment, to understand the social context of power, inequality and social mobility (Mosca 1939; Mills 1956). Research on elites has largely focused upon reproduction and the maintenance of the same families and institutions in dominant social positions. Empirical elite studies have often identified the composition and origins of the elite (Hingley and Moore 2001), for instance through identifying high numbers of powerbrokers following in their fathers' footsteps (Guttsman 1965). A popular characterisation has been the concept of an Inner Circle (Useem 1984) of interconnected actors possessing and sharing power and maintaining their rule through mutual cooperation 
(Mills 1956; Useem 1984). Whilst historically such groups have held similar social backgrounds (Scott 1985), many recent studies have argued this influence is declining as elites are increasingly shaped by their expertise and qualifications, both within the global corporate elite (Heemskerk and Fennema 2009; Carroll 2010) and across the voluntary, political and cultural sectors (Ruostetsaari 2006; Griffiths et al. 2008; Keating and Cairney 2008).

The compositions of elite groups are often compared to the demographics of the population to ascertain inclusiveness (Skelcher and Davis 1995; Terjesen et al. 2009). For instance, many studies in the UK have highlighted the predominance of privately-educated elites (Griffiths et al. 2008; Keating and Cairney 2008; Moran 2003; Guttsman 1965), implying an under-representation of state educated decision-makers and differing processes for ascending towards such positions. A recent development to address demographic deficits is quotas of women in corporate boardrooms, such as seen in Norway (Hoel 2008). The power and influence elites wield present an obvious reason why institutions such as boardrooms should be demographically-representative, yet the argument is not necessarily straightforward. For instance, sometimes it is beneficial to over-represent minority board members to enable multiple social groupings are represented (Skelcher and Davis 1995).

Indeed, boards could be measured as being representative of at least three different populations: the wider population (demographically representative); the stakeholders and communities affected by their work (stakeholder representative); or the pool of potential candidates for such roles who have sufficient prerequisite qualifications (expertise representative). The issue of expertise, however, raises the interesting possibility that whilst inequalities within the composition of elites might stem from social closure amongst the elite, it might equally reflect the impact of wider societal forces in shaping which social groups are most, or least, likely to acquire prerequisite human capital. Whilst there is an expanding literature suggesting social background is lessening in importance in access to elite positions (Ruostetsaari 2006; Griffiths et al. 2008; Keating and Cairney 2008; Heemskerk and Fennema 2009; Carroll 2010), theories of why such expansion has occurred are less developed.

The relationship between human capital and elite recruitment has not been fully explored, meaning it is uncertain whether the demographics of those with the human capital to become elites is shifting, or whether the ability for those with human capital to access such roles have increased. Different models of these processes can then be posited. On the one hand is the scenario where in a society it is relatively difficult to acquire the prerequisite expertise for elite membership, but, once that is obtained, membership is not strongly restricted. We call this scenario the Glastonbury transition (alluding to the famous music festival in the UK, where participants traditionally have some work to purchase expensive heavily-sought tickets and get to the venue but, on entering the festival enjoy access to all acts and areas of the site with few constrains on their options). On the other hand, there is the scenario of a society where it is relatively easy to acquire the prerequisite expertise for elite membership, but subsequent acceptance in influential positions continues to require further assets and characteristics, beyond basic expertise (such as, for instance, favourable social connections). We call this scenario the Wimbledon transition (alluding to the major tennis tournament, where general admission is easily accessible and affordable but most watch the highest profile matches on TV screens inside the venue as 
acquiring tickets for the courts is difficult). Quotas provide an alternative mechanism for advancing to elite positions, although each group will have their own associated transitional path, albeit potentially devaluing the perceived expertise of those fitting such criteria (Bohman et al. 2012).

There are country-level differences around elite recruitment. Sweden, for instance, is often portrayed as having corporate boardrooms governed by a fraternity of older men and their sons (Stafsudd 2006; Jonnergård and Stafsudd 2011), imposing glass ceilings limiting women from higher positions (Albrecht et al 2003) and forming a separate power block to political elites (Rydgren 2005), although such distinctions are dwindling (Bohman et al. 2012; Edling et al. 2014). This tradition of passing governance to sons, and separation of business and state, perhaps originates from the development of Swedish corporations traditionally growing from small, local businesses rather than large, multiple ownership (Glete 1989), with power and influence continuing to operate at localised levels (Edling et al. 2014). Nevertheless, such social closure is at odds with the perception of Sweden as one of the most equal societies (Wilkinson and Pickett 2009) and its high levels of social mobility across the whole occupational structure (Jonsson and Mills 1993), perhaps due to its social democratic history and culture of collectivism leading to social policies tackling the scale of inequalities (Milner 1999, Korpi 1983), rather than focussing on whom benefits the most.

The UK, by contrast, has traditionally framed debates on fairness in terms of a more representative elite which is portrayed as a means of producing policies tackling inequalities (Sampson 1965, Annan 1990). Much research has shown both increasing levels of inter-generational mobility (Goldthorpe and Jackson 2007; Lambert et al. 2007) and patterns of social closure being very gradually attenuated over time amongst both private (Scott 1985) and public (Griffiths et al. 2008; Keating and Cairney 2008) elites with the decline of the 'old boy's network', albeit maintaining an over-representation of those from privileged schools (Maclean et al. 2010; Hill, 2013) and a dominance of London influence upon decision making UK-wide (Griffiths et al. 2008). Increased diversity in the social backgrounds of decision-makers has not prevented the UK continuing to be seen as one of Europe's most unequal societies, performing poorly on a range of social factors (Wilkinson and Pickett 2009).

Whilst large-scale social surveys cannot identify elites from employment data (Verba et al. 1987; Scott 2008; Savage et al. 2013), they can provide contextual data on occupations that elites are often recruited from, such as the directors of companies, charities and professional bodies, high ranking governmental officials and the judiciary (Mills 1956; Sampson 1965; Guttsman 1965; Sampson 2004; Ruostetsaari 2006). Therefore, such groups can provide a proxy for measuring the social and educational backgrounds of those with human capital to access elite positions, which facilitates comparison with the demographics of actual elites. In this paper we explore the backgrounds of people working in such roles in the UK and Sweden, examining how they differ to other occupationally-advantaged groups and what their demographics indicate about the composition of elites in each country.

\section{Data and Methods}


The International Standard Classification of Occupations (ISCO) is a robust and widely used taxonomy of detailed occupational positions. Previous studies (Anson 2004; Hanley and Treiman 2005; Hansson 2013) have attempted to identify elites from broad aggregations of ISCO units (one or two digit clusters), but this method can lead to crude distinctions, such as overstating the relative position of supply and distribution managers within local businesses with a dozen employees (Kramberger and Vehovar 2000). We propose a measure of 'Potential Power Elite' (PPE) using detailed ISCO occupations. Our PPE category captures occupations identified as 'power elites' in sociological studies ${ }^{\mathrm{i}}$, such as the leaders of the business, political, voluntary, military and public sector spheres as have been identified as 'power elites' in sociological studies (Mills 1956; Guttsman 1965; Useem 1984; Ruostetsaari 2006; Maclean et al. 2010).

We have compared the composition of the PPE to three other occupational indicators of 'top' positions; major group 1 from ISCO-88, the Erikson-Goldthorpe-Portocarero (EGP) scheme (Erikson and Goldthorpe 1992) and the CAMSIS scale (www.camsis.stir.ac.uk). The EGP scheme measures advantage in relation to the activities, independence and qualifications of workers and are semi-hierarchal schematics with an identifiable highest level for the most advantaged occupations. The CAMSIS scale provides a continuous scale indicating the average stratification of the incumbents of each occupation, based upon analysis of social interaction patterns (cf. Prandy and Jones 2001). Those individuals occupying an occupation above the $95^{\text {th }}$ percentile of the CAMSIS scale have been coded as holding an advantaged occupation. There is much overlap between the occupations identified in these 'top' classifications and these measures provide a comparison to other occupationallyadvantaged groups. A category of those in major group 1 of ISCO-88 (ISCO1), which contains higher private sector managers irrespective of whether associated with the elite, has been constructed to appraise whether the PPE is capturing different trends to those identified by a wider corporate management groups, which includes non-elite occupations such as hospitality and hotel managers and those in charge of corporate computing systems.

We have analysed elite composition in Sweden and the UK, drawing data from the British Household Panel Survey (BHPS, see University of Essex 2010) and the Swedish Level of Living Survey (LNU) ${ }^{\mathrm{ii}}$. British and Swedish elites are compared due to their contrasting depictions, with Britain being perceived as a close-knit layer of political and business elites (Guttsman 1965; Moran 2003) which is viewed as widening (Griffiths et al. 2008), whilst Sweden traditionally having a divide between its public and private governors (Rydgren 2005), although this distinction is dwindling (Edling et al. 2014). Thus, the UK and Sweden facilitates comparison between two contrasting elite spheres which are, potentially, shifting in differing ways.

The longitudinal surveys allow work-life histories to be constructed for a large nationally representative sample for both countries for the year 2000. The LNU provides complete life history employment on all employment spells and status since the first job held for six months, enabling identification of current or most recent jobs and whether ever holding a 'top' occupation for each category. Work-life history data from the BHPS combined retrospective life history dataset (Halpin 2006) enabled the replication of those variables for the UK. In all cases the occupations have been coded into a standard occupational classification scheme from self-reported data. Occupational coding is ordinarily considered a relatively reliable form of data collection. However for the 
purposes of studying the most advantaged positions misrepresentation is plausible, especially around 'aspirational' job titles. For instance a store supervisor might use the job title 'store manager' and this might be misleadingly coded into a managerial category which implies responsibility for recruitment, disciplinary and procurement practices which might not in practice be performed by the respondent.

Work-life history data is relevant to an occupation-based measure of elite position because we might anticipate a certain degree of maturation time subsequent to obtaining an occupational position before any particular individual is more likely to access positions of genuine power and influence (Härkönen and Bihagen 2011) whilst downward mobility, particularly towards the end of the career, can occur (Bihagen 2007). An occupationbased measure of PPE status should therefore ideally be informed by retrospective career data as well as by current position. Accordingly in our analysis we classify individuals to occupational categories if they have ever held an eligible role in their entire work history. As Figure 1 shows, membership of advantaged groups increases with age, often taking a more quadratic than linear form. We stress that an individual identified as PPE may not necessarily have moved into a position of actual power or influence; our analysis concentrates on accessing occupational positions which provide trajectories into potential elite roles. Furthermore, work history data enables us to analyse whether people retain such roles throughout the remainder of their careers, which we believe is a proxy for whether they are progressing, or regressing, in their careers.

\section{Attaining and retaining advantaged occupational status}

$U K$

The composition of all advantaged occupational groupings, as shown in Table 1, shows higher levels than the national average for having parents from EGP service classes I and II, holding degrees, and attending private or grammar schools. This implies there is a different between the expected profiles of a demographically representative and expertise representative social elite. We find certain consistencies between individuals in the three traditional occupation-based measures, though with less advantaged social and educational background for ISCO1 than the CAMSIS and EGP schemes. The correlation coefficients shown in Table 2 demonstrate that the three measures have moderate, but far from complete, overlap of membership.

\section{<TABLE 1 ABOUT HERE>}

$<$ TABLE 2 ABOUT HERE>

The PPE category could be thought of as differing to the other measures of advantage. Sociologically-derived schematics are designed to characterise wider distributional patterns of inequality, but the PPE category is designed as an indicator of a position within a specified advantaged grouping. For instance, whilst dentists might score highly in terms of relative social position, they are unlikely to wield much wider social influence. Indeed, Table 2 shows a low correlation between the PPE and CAMSIS variable and moderate correlation 
between PPE and EGP. We also find that the PPE comprise 54.5\% males, which is much lower than the proportion within observed elite groups (Maclean et al. 2010; Griffiths et al. 2008).

Table 1 shows several indicators of the role of parental position in respondents' classification to a 'top' position. For the UK sample, parental occupational background, shown here in terms of EGP class position, and parental mean CAMSIS, is broadly similar across each measure and show a more advantaged background than the wider population. Educational influence is shown by having obtained a degree and, for the UK, attendance at private schools, both for the members of the occupational groupings but also for the children (over the age of 25) of those in such roles. There is an apparent over-use of advantaged schools by the parents within the PPE classification, replicated only amongst ISCO1; other literature has consistently linked private and exclusive schooling with the securitising elite positions (e.g. Scott 1995). Lastly, the table shows proportions and odds ratios from those having parents in the same advantaged positions given their own advantaged status. The proportions reported may seem low across all schemes. In part this reflects a genuine pattern of openness within the advantaged categories (i.e. the large majority of those in each category have parents whose occupations do meet the criteria for inclusion). However these values are also influenced by the relatively small proportions within the advantaged groups overall. The high odds ratios, comparable in magnitude across all measures, may give a more realistic impression of the relative improvement in chances of a respondent obtaining the same status as their parents.

The strongest distinction between the PPE and other advantaged groupings appears to be in educational backgrounds. 59\% of PPE's hold degrees, compared to between $62 \%$ and $67 \%$ for other groupings, suggesting that whilst the PPE are more likely to be graduates than the wider population, they are not as highly educated as other advantaged groups (perhaps, in part, to the exclusion of doctors, lawyers and academics). The correlations between the two educational criteria and advantaged status in Table 2 reiterate this: PPE has a correlation of just .09 with measures of attending advantaged schools and possessing degrees, against a range for the top levels of CAMSIS and EGP of .22 and .21 respectively for school and .27 and .34 for degrees. On the other hand, the PPE are much more likely to provide an advantaged education to their offspring, having the highest levels of children in such schools. Thus, the educational background of the pool of talent the power elite are recruited from could be viewed as more highly educated that the overall population, but not as much so as other advantaged groups. However, studies into British elites frequently find much higher levels of privileged education; for instance, $88 \%$ of top corporate directors attended private schools (Maclean et al. 2010) and 80\% of Conservative MPs in 2012 were graduates and 54\% had attended private schools (Hill 2013), implying process other than human capital are responsible for this over-representation.

\section{Sweden}

The Swedish data shows a stronger contrast between the PPE and the other advantaged groups. Across all indicators (see Tables 1and 3) there is relative similarity between the most advantaged groups of the EGP and CAMSIS classifications. In these groups there is a preponderance of males; around twice as many advantaged 
people have Service Class I parents as the overall population; similar levels of university education; and the odds ratios for having a parent within the advantaged group are 2.4 and 2.6.

\section{<TABLE 3 ABOUT HERE>}

The PPE measure is distinctive to other advantaged Swedish groups, being older, more masculine and more likely to have self-employed parents: perhaps suggesting a continued process of Swedish business elites holding ties to smaller, localised businesses (Glete 1989). Whilst the PPE features a similar, if somewhat smaller, percentage of graduates, its members appear less likely to see their children attend university than those in advantaged CAMSIS or EGP occupations. More strikingly, the odds of a PPE member having a parent who is likewise was 3.5, much higher than for other measurements of social advantage, implying a greater degree of fraternal recruitment. ISCO1 were less likely than the PPE to have a service class I parent or reproduce social position, perhaps due to the many lower grade occupations within the category. These results support the views that Swedish corporate directors are traditionally recruited from a small pool, often being the sons of the existing corporate classes (Stafsudd 2006) and the political elite is drawn from parents with a stratification position higher than the overall population but lower than other advantaged groups (Hansson 2013). Unlike the UK, Sweden possesses evidence of Glastonbury style recruitment, with greater social closure for the PPE.

Differences occur between the PPE and other advantaged groups within both the UK and Sweden. In both countries, educational attainment does not appear as strong a requirement for access to the PPE category as for other groupings, possibly due to occupations which require high levels of qualifications, such as medical doctors, solicitors and academics, not being included. Alternatively, this could indicate that individuals can progress to PPE positions regardless of educational qualifications. Within the UK, whilst PPE's do not possess particularly strong educational backgrounds, they appear to prioritise this amongst their offspring. This could indicate that higher managerial roles offer a way for people to become professionals, acting similarly to other advantaged groups once attaining such positions. For Sweden, educational attainment of the children of PPE's is distinctively lower, despite higher levels of children following their parents into similar occupations. This could suggest educational background is less important for Swedish elites, perhaps with heightened focus on experience or greater utilisation of social connections.

\section{Stability in elite positions}

The preceding analysis used life-history data to analyse measures of whether people ever held positions of occupational advantage during their careers. For some people attainment of such a position will continue until retirement. For others, downward mobility will take place (Bihagen 2007). Downward mobility might occur for various reasons, including career choice, and does not necessarily represent social disadvantage. However by our conceptualisation of 'potential' elites, we would theorise that sustained membership is ordinarily required to translate that potential into realised power, and therefore analysis of long-term stability within the elite level is relevant. 
Analysis of career stability reveals some apparent problems with the classification of occupations and coding of individuals as advantaged. For example the 'Chief executives' occupational unit group code, in both the UK and Swedish data, appears to often identify people who have since gone back to other less advantaged roles.

'Mechanical engineers', also coded as advantaged by many schemes, are often individuals who subsequently hold jobs as maintenance workers. Some 'Production managers' have a work history profile suggesting they are shop or factory workers briefly given a supervisory role. These examples suggest that some of the individuals captured as members of the PPE are likely to have been miscoded rather than possessing experience and expertise likely to lead to elite recruitment, but we are unable to suggest meaningful systematic alterations in defining the PPE on the basis of occupations which are likely to be more accurate.

Analysis of retainment levels within occupational groupings shows a distinction between the PPE and other occupational groupings in both the UK and Sweden. Table 4 shows descriptive statistics for the UK on each measure by whether individuals, who had ever achieved such a position, had continued to do so in their most recent job. Significant differences at the $5 \%$ level between those remaining in positions and those who have exited are shown in bold. The PPE are more likely to retain such roles if they have a Service Class I parent or a higher parental CAMSIS. Age was the only other significant factor.

\section{<TABLE 4 ABOUT HERE>}

EGP similarly showed an effect for Service Class I background, but also for university education. The CAMSIS measure showed no significant relationships with retention aside from age and gender. The PPE, therefore, appears to have retainment associated solely with parental effects. This was also true for ISCO1, with greater levels of remaining in positions if having a parent from that group, although no significant effect for the highest EGP category. This implies that the PPE is capturing different processes to ISCO1 and suggests Wimbledon style PPE recruitment, with those able to retain positions of potential power and elite more likely to come from certain social backgrounds.

In Sweden (see Table 5) there were no significant differences between those PPE's who remained, and those who left it. As with the UK, for the EGP measure university attendance was a significant benefit towards stability but there were no additionally significant social background effects, implying within Sweden social background is not a strong indicator of whether people will remain in an advantaged profession net of education. However, whilst no significant effects were found for the PPE, ISCO1 showed parental effects on retention using parental CAMSIS and EGP. This implies not only does Sweden also see a difference between the circumstances of the power elite and wider corporate managers, but this occurs in a contrasting way to the UK. This lack of effects for PPE retention conflicts with earlier research on Sweden but could be explained by the dominance of males within the occupations, as downward mobility has been shown to be more closely associated with women (Bihagen 2007). It provides evidence of Glastonbury style transition, with a crosssection of society more likely to attain advantageous positions, but little distinction made between those who reach such roles. 


\section{<TABLE 5 ABOUT HERE>}

In summary, within both the UK and Sweden, the PPEs' ability to retain advantaged positions appears less related to their educational background than is retention in the advantaged groups of the EGP measure, possibly as many professional jobs with degree requirements are part of the these groupings but not the PPE. The lack of influences on PPE retainment in Sweden could imply the factors identified as influencing recruitment provide little further assistance once positions are obtained (i.e. that unmeasured performance factors influence retainment). By contrast, whilst the UK appears more open in terms of allowing access to PPE role, social background appears to hold a larger effect for retainment, whilst higher educational attainment may even be a slight disadvantage to retaining a position, perhaps suggesting that although credential-based mobility into elite positions is possible, it is difficult to retain position over time without a favourable background.

\section{Discussion}

This paper has analysed different measures of advantaged occupational groupings in the UK and Sweden to assess if processes of social mobility within the country are reflected in how people access elite trajectory occupations. Occupation-based measures could provide convenient tools for analysing social elites, and we suggest that labelling the categories identified as providing the potential for their incumbents to experience elite levels of power and influence is an effective strategy to measuring elites through occupational data.

In the UK the patterns of social mobility for potential power elite (PPE) was broadly similar to established occupational measures, albeit with a lower odds ratio of having a similarly advantaged parent and an increased tendency to retain positions if deriving from more advantaged backgrounds. The similarity of measures should, perhaps, be expected given the occupations included within the PPE are largely a subset of those within the other categories. However, evidence of Wimbledon style recruitment could be observed, with social background not being a barrier to access the human capital required for elite roles but social background being important for retaining positions towards the top and, presumably, accessing higher positions.

Sweden, by contrast, showed evidence of Glastonbury style recruitment, with a greater association between background and entry but apparent equity between those once in such positions. The PPE in Sweden are more likely to be male, and less likely to be graduates, than members of the other advantageous groups (of which, of course, the PPE largely form a part). They are also more likely to have followed their parents into such roles than the advantaged using other measures and less likely to see their children acquire the human capital of university attendance. However, there were no significant differences between those who retained and exited such careers, despite education, age and gender being associated with retention for other measures.

Comparatively, this implies that the access to the elite in the UK mirrors other forms of social mobility, whereas in Sweden recruitment to elite trajectory careers is more associated with social background than entry into other privileged occupations. Within the UK a wider portion of society can access PPE roles yet, once obtained, those 
who grew up in advantaged circumstances are given an apparent benefit. In Sweden people from a selfemployed household are more likely to access a PPE role than another advantaged role. It is plausible that the differing social environment in each country could be responsible for this, with the UK having a long tradition of policy support for social mobility leading to initial access to managerial roles but more competition subsequently (Goldthorpe and Jackson 2007) whilst Sweden's traditions of equality could see pressures to prevent the advantaged becoming disproportionately powerful and less attention paid to ensure access to all occupations. Our findings mirror those of Jonsson and Mills (1993) who linked national differences between Sweden and the UK to their social mobility strategies. Whilst the literature might suggest Sweden retains a closed capitalist class (Albrecht et al. 2003; Stafsudd 2006) whilst the UK's elite circles are widening (Griffiths et al. 2008; Maclean et al. 2010), this analysis suggests whilst there are shorter-term differences in accessing such roles, longer-term assimilation into such circles is relatively similar.

As a measure, the PPE is consistent with analysis of existing analyses of elite groups. The Swedish elites for instance, are shown to have more advantaged social backgrounds than the overall population but not other advantaged occupational groups, supporting findings from a study of parliamentarians (Hansson 2013). Our method facilitates understanding why certain groups are under-represented amongst elites, in Sweden through limited access positions related to elite recruitment and in the through precariousness once in such roles. It should not be overlooked, however, that both the distribution of occupations within the PPE and the social meaning of a university education differs between the UK and Sweden, whilst the distinction between localised and London-centric power could also influence elite recruitment processes. The PPE includes not only corporate governors, but also leading trade unionists, charity chief executives and military officers, occupations which could differ substantively between countries with contrasting attitudes towards equality (Korpi 1983; Annan 1990; Wilkinson and Pickett 2009).

The PPE measure provide insights to slightly different elements of occupational attainment than existing schemes, implying the trajectories into roles of potential social influence can differ to accessing advantageous jobs. Secondary school teachers, solicitors and medical doctors hold little political or social influence compared to, for instance, corporate directors or leading trade unionists, and this analysis suggests, in Sweden and arguably the UK, that the demographics of such groups differ. Similarly, the PPE measure differs to a simplified coding of the first ISCO-88 major group, which broadly corresponds with corporate managers. However, there are limitations to the use of the indicator. In both the UK and Sweden some individuals were observed who met the PPE criteria but had a work history profile which did not suggest elite status. These issues appear to be caused by the difficulties of coding job titles, but cannot readily be addressed by modifying the definition of PPE occupations. This limitation applies to all occupational aggregation schemes, however. Additionally, it is possible that the PPE captured by a social survey will be unrepresentative of the elite group as a whole (for instance, an underrepresentation of political party senior officials compared to business leaders). Coupled with the possibility of differences within elite composition between nations, there is clearly a need for care in using a PPE indicator. 
In this paper we demonstrate that occupations can be utilised for analysing the composition of elite groups, producing results which are consistent with theories of elite recruitment and social mobility more generally in the UK and Sweden. In both countries, we demonstrate that the PPE are not representative of the wider population, suggesting that an expertise representative elite would have a more advantaged background than a demographically representative elite. However, comparisons with observed elites suggest that background matters even amongst those with sufficient human capital, especially within the UK with its tendency to recruit from private schools. The rich availability of social surveys, alongside studies of elite composition, facilitates longitudinal studies of both long-term changes in both elite composition and recruitment. Indeed, studies into the glass ceiling effects for elite recruitment can adopt these methods to understand whether those powerful groups which are unrepresentative of wider society are demonstrating expertise representation through selecing members equally from all with prerequisite human capital. Such studies, similarly, can reconstitute our PPE to contain those occupations which are found amongst the career history of the studied elite, and indeed weight cases accordingly. Therefore, this approach can facilitate answering the hitherto unanswered wider question implied by numerous contemporary elite studies; why are elites increasingly recruited from a wider crosssection of society.

\section{References}

Albrecht, J., Björklund, A. and Vroman, S., (2003) 'Is There a Glass Ceiling in Sweden?', Journal of Labor Economics, 21 (1): 145-177.

Annan, N., (1990) Our Age, London: Fontana.

Anson, J. (2004) 'The Migrant Mortality Advantage: A 70 Month Follow-up of the Brussels Population', European Journal of Population, 20, 191-218.

Ashley, L. (2010) 'Making a difference? The use (and abuse) of diversity management at the UK's elite law firms, Work Employment and Society, 24(4), 711-727.

Bihagen, E. (2007) 'Class Origin Effects on Downward Career Mobility in Sweden 1982-2001', Acta Sociologica, 50, 415-430.

Bohman, L., Bygren, M., and Edling, C. (2012) 'Siege under threat: The rapid increase of women on Swedish boards of directors' In C. Fagan, M.C. González Menéndez and S. Ansón Gómez (eds.) Women on Corporate Boards and in Top Management: European Trends and Policy. Basingstoke: Palgrave Macmillan.

Bourdieu, P. (1984) Distinction, London: Routledge.

Carroll, W.K. (2010) The Making of the Transnational Capitalist Class, New York: Zed Books.

Edling, C., Farkas, G., and Rydgren, J. (2014) 'Integration of the Swedish Local Elite: The Role of Professional and Private Networks', Scandinavian Political Studies, DOI: 10.111/1467_9477.12023..

Erikson, R., and Goldthorpe J H. (1992) The Constant Flux, Oxford: Clarendon Press. 
Glete, J. (1989) 'Long-Term Firm Growth and Ownership Organization: A Study of Business Histories', Journal of Economic Behaviour and Organisation, 12, 329-351.

Goldthorpe, J. H., and Jackson, M. (2007). Intergenerational class mobility in contemporary Britain: political concerns and empirical findings. British Journal of Sociology, 58(4), 525-546.

Griffiths, D., Miles, A. and Savage, M. (2008) 'The End of the English Cultural Elite?, Sociological Review, 56(s1), 187-209.

Guttsman, W. C. (1965) The British Political Elite, London: MacGibbon and Kee Ltd.

Halpin, B. (2006). British Household Panel Survey Combined Work-Life History Data, 1990-2005 [computer file]. 5th ed. Colchester, Essex: Institute for Social and Economic Research, [original data producer(s)]. UK Data Archive [distributor], November 2006. SN: 3954.

Hanley, E., and Treiman, D. J. (2005) 'Recruitment into the Eastern European Communist Elite: Dual career paths', Research in Social Stratification and Mobility, 23, 35-66.

Hansson, J.L. (2013) Gender Inequality among Political Elites in Comparative Perspective, PhD thesis, European University Institute, Florence.

Härkönen, J. and Bihagen, E. (2011). 'Occupational attainment and career progression in Sweden'. European Societies, 13(3): 451-479.

Heemskerk, E., and Fennema, M. (2009) 'Network Dynamics of the Dutch Business Elite', International Sociology, 24 (6), 807-832.

Henry, R., and Saunders, J. (2012) 'UK dotted with foreign elites in "golden clusters"', The Times, 18 November.

Hill, M. (2013) 'Arrogant Posh Boys? The Social Composition of the Parliamentary Conservative Party and the Effects of Cameron's “A” List”, Political Quarterly, 84(1), 80-89.

Hoel,, M. (2008) 'The quota story: Five years of change in Norway' In S. Vinnicombe, V. Singh, R. Burke, D. Bilmoria, and M. Huse (eds.) Women on Corporate Boards of Directors: International Research and Practice, Cheltenham: Edward Elgar.

Hingley, J. and Moore, G. (2001) Political Elite Studies in the Year 2000. International Review of Sociology, 11, 175180.

Jonnergård, K and Stafsudd, A. (2011) 'The making of active boards in Swedish public companies', Journal of Managemen and Governance, 15 (1), 123-155.

Jonsson, J. O., and Mills, C. (1993). 'Social mobility in the 1970's and 1980's: A study of men and women in England and Sweden', European Sociological Review, 9(3), 229-248.

Keating, M. and Cairney, P. (2006) 'A New Elite? Politicians and Civil Servants in Scotland after Devolution', Parliamentary Affairs, 59 (1), 43-59.

Korpi, W. (1983) The Democratic Class Struggle, London: Routledge and Kegan Paul Ltd. 
Kramberger, A., and Vehovar, V. (2000) 'Regime Change and Elite Dynamics in Slovenia during the 1990s: what can the elite reproduction rates tell us?', Družboslovne Razprav, 32-33, 143-180.

Lambert, P., Prandy, K., and Bottero, W. (2007) 'By Slow Degrees: Two Centuries of Social Reproduction and Mobility in Britain', Sociological Research Online, 12 (1).

Larivière, V., Macaluso, B., Archambault, E., and Gingras, Y. (2010) 'Which scientific elites? On the concentration of research funds, publications and citations', Research Evaluation, 19(1), 45-53.

Maclean, M., Harvey, C., and Chia, R. (2010) 'Dominant Corporate Agents and the Power Elite in France and Britain', Organization Studies, 31, 327-348.

Mason, R. (2013) 'Labour's Chuka Umunna under fire for labelling people 'trash' on elite social network', Telegraph, 5 April.

Mills, C. W. (1956) The Power Elite, New York, Oxford University Press.

Milner, A. (1999) Class, London: Sage.

Moran, M. (2003) The British Regulatory State, Oxford: Oxford University Press.

Mosca, G. (1939) The Ruling Class. New York: McGraw-Hill.

Prandy, K., and Jones, L. (2001) ‘An international comparative analysis of marriage patterns and social stratification', International Journal of Sociology and Social Policy, 21, 165-183.

Ruostetsaari, I. (2006) 'Social Upheaval and Transformations of Elite Structures: The Case of Finland', Political Studies, 54, 23-42.

Rydgren, J. (2005) 'Bridging Different Worlds? Economy, Politics and Brokerage Roles in Sweden', Acta Sociologica, 48, 117-129.

Sampson, A. (1965) Anatomy of Britain. London: Hodder and Stoughton.

Sampson, A. (2004) Who Runs This Place? The Anatomy of Britain in the 21st Century, London: John Murray.

Savage, M., Devine, F., Cunningham, N., Taylor, M., Li, Y., Hjellbrekke, J., Le Rouz, B., Friedman, S., and Miles, A. (2013) 'A New Model of Social Class? Findings from the BBC's Great British Class Survey Experiment', Sociology, 47(2), 219-250.

Scott, J., (1985) Corporations, Classes and Capitalism,. London: Hutchinson, second edition.

Scott, J.(1995) Who Rules Britain?, Cambridge: Polity.

Scott, J. (2008) 'Modes of Power and the re-conceptualization of elites', Sociological Review, 56(s1), 25-43.

Skelcher, C., and Davis, H. (1995) Opening the Boardroom Door: The Membership of Local Appointed Bodies. London: LGC Communications.

Stafsudd, A. (2006) 'People are strange when you're a stranger: Senior executives select similar successors', European Management Review, 3(3), 177-189. 
Terjesen, S., Sealy, R., and Singh, V. (2009) 'Women Directors on Corporate Boards: A Review and Research Agenda', Corporate Governance: An International Review, 17 (3), 320-337.

University of Essex, and Institute for Social and Economic Research. (2010) British Household Panel Survey: Waves 1-18, 1991-2009 [computer file], 7th Edition. Colchester, Essex: UK Data Archive [distributor], July 2010, SN: 5151.

Useem, M., (1984) The Inner Circle, Oxford: Oxford University Press.

Verba, S., Kelman, S., Orren, G.R., Miyake, I., Watanuki, J., Kabashima, I., and Ferree, G.D. (eds). (1987) Elites and the Idea of Equality: A comparison of Japan, Sweden, and the United States. London: Havard University Press.

Wilkinson, R., and Picket, K. (2009) The Spirit Level, London: Penguin. 
Membership of occupationally advantage groups, by age

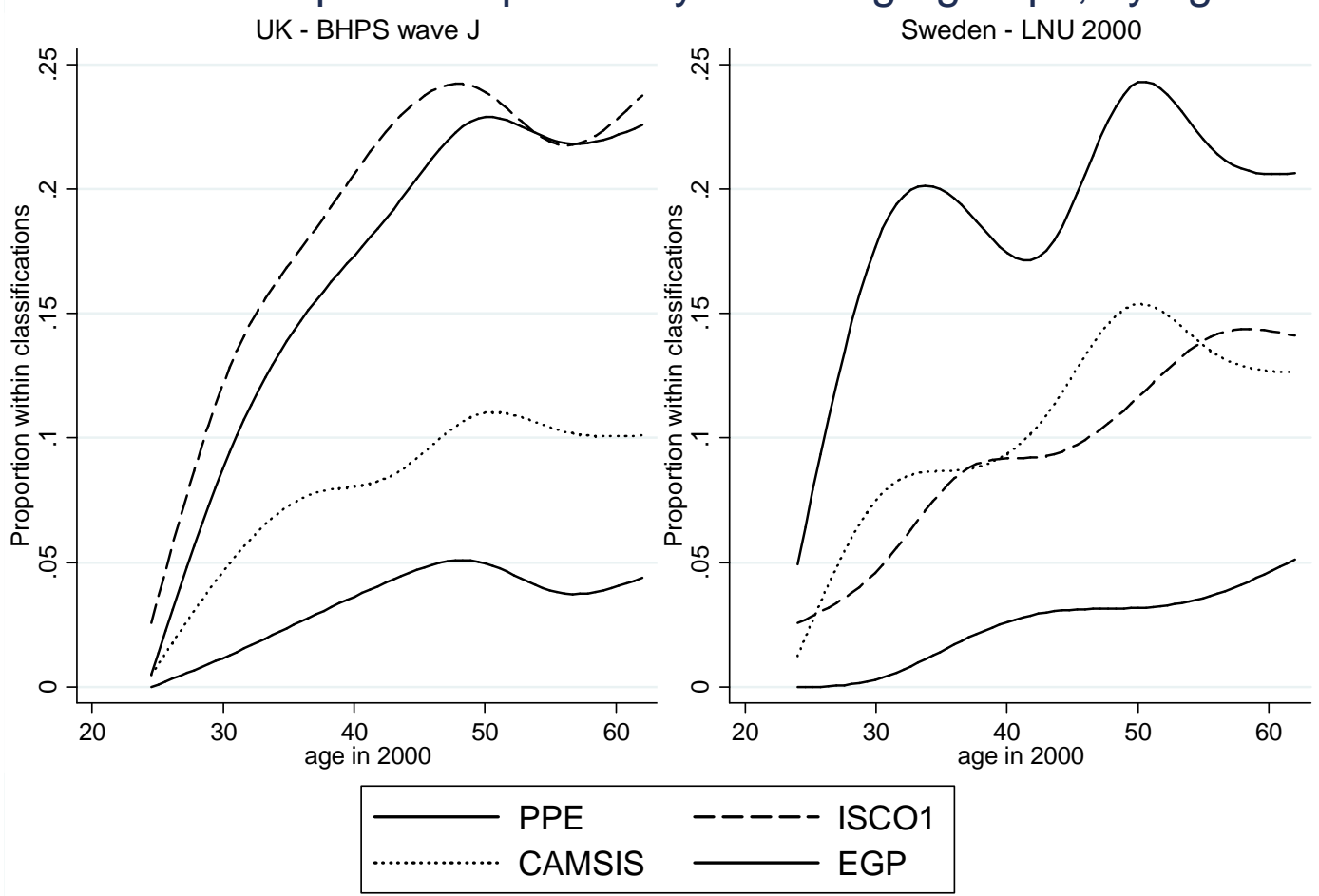

Figure 1: Membership of occupationally advantaged groups, by age (graphs smoothed) 


\begin{tabular}{|c|c|c|c|c|c|c|c|c|c|c|c|}
\hline & & \multicolumn{5}{|l|}{ UK } & \multicolumn{5}{|l|}{ Sweden } \\
\hline & & \multicolumn{4}{|c|}{ Cases in 'advantaged' category using... } & \multirow{2}{*}{$\begin{array}{l}\text { All } \\
\text { cases }\end{array}$} & \multicolumn{4}{|c|}{ Cases in 'advantaged' category using... } & \multirow{2}{*}{$\begin{array}{l}\text { All } \\
\text { cases }\end{array}$} \\
\hline & & PPE & ISCO1 & CAMSIS & EGP & & PPE & ISCO1 & CAMSIS & EGP & \\
\hline & Number of cases & 336 & 1,614 & 796 & 1,629 & 7,869 & 137 & 517 & 689 & 1,017 & 5,523 \\
\hline & $\begin{array}{l}\text { Percent male } \\
\text { Average age in years }\end{array}$ & $\begin{array}{r}54.5 \% \\
53.6\end{array}$ & $\begin{array}{r}59.0 \% \\
54.0\end{array}$ & $\begin{array}{r}47.4 \% \\
53.1\end{array}$ & $\begin{array}{r}61.6 \% \\
53.2\end{array}$ & $\begin{array}{r}47.0 \% \\
53.8\end{array}$ & $\begin{array}{r}74.5 \% \\
52.2\end{array}$ & $\begin{array}{r}68.7 \% \\
51.8\end{array}$ & $\begin{array}{r}53.1 \% \\
49.3\end{array}$ & $\begin{array}{r}63.6 \% \\
48.0\end{array}$ & $\begin{array}{r}51.1 \% \\
47.1\end{array}$ \\
\hline $\begin{array}{l}\text { Parents EGP Class } \\
\text { (highest class of either } \\
\text { parent) }\end{array}$ & $\begin{array}{l}\text { Service I } \\
\text { Service II } \\
\text { Self-employed } \\
\text { Other }\end{array}$ & $\begin{array}{l}29.7 \% \\
12.3 \% \\
12.7 \% \\
45.3 \%\end{array}$ & $\begin{array}{l}19.9 \% \\
10.4 \% \\
19.4 \% \\
50.3 \%\end{array}$ & $\begin{array}{l}32.9 \% \\
14.7 \% \\
14.0 \% \\
38.4 \%\end{array}$ & $\begin{array}{l}27.0 \% \\
13.1 \% \\
15.0 \% \\
44.9 \%\end{array}$ & $\begin{array}{r}14.4 \% \\
9.0 . \% \\
15.7 \% \\
60.9 \%\end{array}$ & $\begin{array}{l}23.4 \% \\
13.9 \% \\
27.0 \% \\
35.8 \%\end{array}$ & $\begin{array}{l}18.4 \% \\
14.3 \% \\
25.7 \% \\
41.6 \%\end{array}$ & $\begin{array}{l}24.2 \% \\
15.0 \% \\
20.9 \% \\
39.9 \%\end{array}$ & $\begin{array}{l}27.2 \% \\
17.9 \% \\
19.3 \% \\
35.6 \%\end{array}$ & $\begin{array}{l}12.4 \% \\
12.1 \% \\
24.7 \% \\
50.8 \%\end{array}$ \\
\hline Advantaged school & $\begin{array}{l}\text { Self -attended } \\
\text { Attended if parent advantaged }\end{array}$ & $\begin{array}{l}36.1 \% \\
45.1 \%\end{array}$ & $\begin{array}{l}27.6 \% \\
36.0 \%\end{array}$ & $\begin{array}{l}45.8 \% \\
39.7 \%\end{array}$ & $\begin{array}{l}36.2 \% \\
37.6 \%\end{array}$ & $\begin{array}{l}19.6 \% \\
19.6 \%\end{array}$ & $\begin{array}{l}- \\
-\end{array}$ & & $\begin{array}{ll}- \\
-\end{array}$ & $\begin{array}{l}- \\
-\end{array}$ & - \\
\hline University & $\begin{array}{l}\text { Attended university } \\
\text { Attended if parent advantaged }\end{array}$ & $\begin{array}{l}59.2 \% \\
59.0 \%\end{array}$ & $\begin{array}{l}50.3 \% \\
62.1 \%\end{array}$ & $\begin{array}{l}77.9 \% \\
65.7 \%\end{array}$ & $\begin{array}{l}70.7 \% \\
67.1 \%\end{array}$ & $\begin{array}{l}38.7 \% \\
38.8 \%\end{array}$ & $\begin{array}{l}49.6 \% \\
36.2 \%\end{array}$ & $\begin{array}{l}54.4 \% \\
23.2 \%\end{array}$ & $\begin{array}{l}56.0 \% \\
53.8 \%\end{array}$ & $\begin{array}{l}59.9 \% \\
53.3 \%\end{array}$ & $\begin{array}{l}22.4 \% \\
23.5 \%\end{array}$ \\
\hline $\begin{array}{l}\text { Parent advantaged using } \\
\text { similar criteria }\end{array}$ & $\begin{array}{l}\text { Amongst advantaged } \\
\text { Amongst non-advantage } \\
\text { Odds ratio } \\
\text { Child in Service Class I } \\
\text { Highest parental CAMSIS (mean) }\end{array}$ & $\begin{array}{r}3.2 \% \\
2.0 \% \\
1.6 \\
31.7 \% \\
51.9\end{array}$ & $\begin{array}{r}15.0 \% \\
9.5 \% \\
1.6 \\
40.0 \% \\
49.2\end{array}$ & $\begin{array}{r}18.3 \% \\
6.4 \% \\
2.9 \\
38.5 \% \\
55.7\end{array}$ & $\begin{array}{r}27.0 \% \\
10.8 \% \\
2.5 \\
42.1 \% \\
52.0\end{array}$ & $\begin{array}{r}- \\
- \\
20.7 \% \\
45.9\end{array}$ & $\begin{array}{r}8.2 \% \\
2.4 \% \\
3.5 \\
36.9 \% \\
60.6\end{array}$ & $\begin{array}{r}6.1 \% \\
2.4 \% \\
2.6 \\
27.1 \% \\
62.4\end{array}$ & $\begin{array}{r}12.8 \% \\
5.2 \% \\
2.4 \\
39.0 \% \\
61.3\end{array}$ & $\begin{array}{r}40.5 \% \\
15.3 \% \\
2.6 \\
40.4 \% \\
61.8\end{array}$ & $\begin{array}{r}- \\
- \\
- \\
18.4 \% \\
56.9\end{array}$ \\
\hline
\end{tabular}

Table 1: Occupation-based measures in the UK and Sweden.

Source: BHPS (wave J, 2000) for the UK; Swedish Level of Living Survey (2000) (unweighted data). Measures are based on the full occupational life history for those cases in each dataset with valid life-course occupational data. An 'advantaged' status is defined as the individual ever having had an occupation classified within the category at any stage of their work history. 


\begin{tabular}{|c|c|c|c|c|c|c|c|c|}
\hline & $\begin{array}{l}\text { Age } \\
\text { (decade) }\end{array}$ & Gender & School & Degree & PPE & ISCO1 & CAMSIS & EGP \\
\hline Gender & .0570 & & & & & & & \\
\hline Adv. School & .1929 & .0063 & & & & & & \\
\hline Degree & .2489 & -.0838 & .1894 & & & & & \\
\hline PPE & .0840 & -.0315 & .0886 & .0889 & & & & \\
\hline ISCO1 & .0069 & -.1370 & .1151 & .1360 & .3345 & & & \\
\hline CAMSIS & .0963 & .0023 & .2216 & .2697 & .1313 & .0635 & & \\
\hline EGP & .1497 & -.1490 & .2141 & .3356 & .2768 & .3332 & .4436 & \\
\hline Parental EGP & .1557 & .0262 & .1675 & .2246 & .0954 & .0916 & .1840 & .1928 \\
\hline
\end{tabular}

Table 2: Correlations within UK data (Bivariate correlation for all variables, except for age correlations which show pseudo-R from logistic regression with age group dummy variables).

\begin{tabular}{|l|lll|llll|}
\hline & Male & Age & Degree & PPE & ISCO1 & CAMSIS & EGP \\
\hline Age & .0245 & & & & & & \\
Degree & .0601 & -.0836 & & & & & \\
\hline PPE & .0745 & .0539 & .1044 & & & & \\
ISCO1 & -.062 & .0745 & .1154 & .4659 & & & \\
CAMSIS & -.0152 & .0054 & .3048 & .2745 & .3219 & & \\
EGP & .1190 & .0292 & .4277 & .3267 & .2853 & .5374 & \\
\hline Parental EGP & .0130 & -.1080 & .1845 & .0438 & .0768 & .1114 & .1736 \\
\hline
\end{tabular}

Table 3: Correlations within Swedish data (Bivariate correlation for all variables, except for age correlations which show pseudo-R from logistic regression with age group dummy variables). 


\begin{tabular}{|c|c|c|c|c|c|c|c|c|c|c|}
\hline & \multicolumn{2}{|l|}{ PPE } & \multicolumn{2}{|l|}{ ISCO1 } & \multicolumn{2}{|l|}{ CAMSIS } & \multicolumn{2}{|l|}{ EGP } & \multirow[t]{2}{*}{ All } \\
\hline & & Remain & Exited & Remain & Exited & Remain & Exited & Remain & Exited & \\
\hline & Number of cases & 123 & 158 & 977 & 637 & 335 & 353 & 950 & 447 & 6,295 \\
\hline & Male & $49.6 \%$ & $50 \%$ & $61.8 \%$ & $54.8 \%$ & $57.3 \%$ & $38.0 \%$ & $59.6 \%$ & $58.8 \%$ & $48.1 \%$ \\
\hline & Average age & 47.6 & 50.6 & 48.8 & 50.0 & 48.6 & 50.6 & 48.8 & 50.8 & 47.6 \\
\hline \multirow{4}{*}{$\begin{array}{l}\text { Parents EGP Class } \\
\text { (highest class of either } \\
\text { parent) }\end{array}$} & Service I & $41.1 \%$ & $26.6 \%$ & $23.3 \%$ & $19.7 \%$ & $35.7 \%$ & $33.5 \%$ & $30.6 \%$ & $25.0 \%$ & $16.4 \%$ \\
\hline & Service II & $12.2 \%$ & $14.0 \%$ & $12.4 \%$ & $8.7 \%$ & $14.5 \%$ & $14.7 \%$ & $13.7 \%$ & $11.3 \%$ & $9.5 \%$ \\
\hline & Self-employed & $10.3 \%$ & $13.3 \%$ & $18.0 \%$ & $20.3 \%$ & $11.8 \%$ & $15.1 \%$ & $13.9 \%$ & $17.2 \%$ & $15.7 \%$ \\
\hline & Other & $36.5 \%$ & $46.2 \%$ & $46.4 \%$ & $51.4 \%$ & $38.1 \%$ & $36.7 \%$ & $41.8 \%$ & $46.6 \%$ & $58.5 \%$ \\
\hline Advantaged school & Self -attended & $30.0 \%$ & $31.9 \%$ & $25.8 \%$ & $25.0 \%$ & $42.5 \%$ & $43.3 \%$ & $33.1 \%$ & $34.0 \%$ & $18.0 \%$ \\
\hline University & Attended university & $58.6 \%$ & $60.8 \%$ & $54.2 \%$ & $53.5 \%$ & $83.0 \%$ & $78.8 \%$ & $74.0 \%$ & $68.7 \%$ & $43.1 \%$ \\
\hline \multirow{2}{*}{\multicolumn{2}{|c|}{$\begin{array}{l}\text { Parent advantaged using same criteria } \\
\text { Highest individual parental CAMSIS }\end{array}$}} & $6.2 \%$ & $2.0 \%$ & $18.5 \%$ & $13.6 \%$ & $19.4 \%$ & $18.4 \%$ & $30.6 \%$ & $25.0 \%$ & - \\
\hline & & 55.3 & 51.1 & 50.2 & 49.1 & 56.7 & 55.8 & 53.1 & 51.7 & 46.9 \\
\hline
\end{tabular}

Table 4: Differences between those who drop out of categories and those who remain in the UK

Note: Bold indicates a statistically significant difference between those who remain in advantaged categories and those who exit.

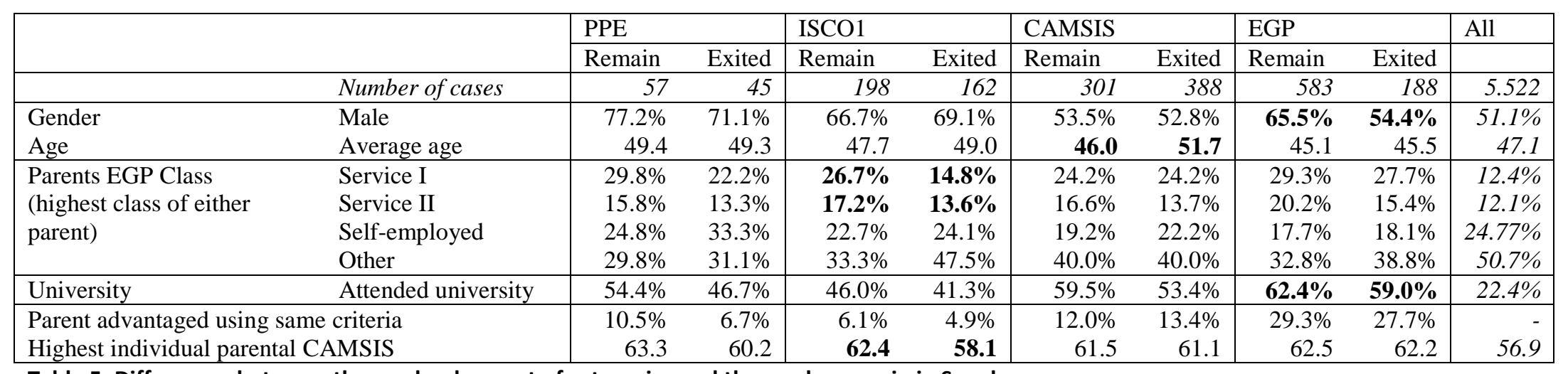

Table 5: Differences between those who drop out of categories and those who remain in Sweden

Note: Bold indicates a statistically significant difference between those who remain in advantaged categories and those who exit. 


\footnotetext{
${ }^{\mathrm{i}}$ Specifically, these are: legislators, senior government officials and traditional chiefs (ISCO-88 codes 11, 111, 1110); senior officials of political parties, employers' associations, charities and other special interest groups $(114,1141,1142,1143)$; corporate directors, chief executives, financial managers, chief accountants and research managers $(12,121,1210,1231,1232,1237)$; military officers $(1250,1251,1252)$; and judges $(2422)$. ${ }^{\text {ii }}$ In the British data, occupations were originally coded into the UK SOC-90 scheme then translated to ISCO-88 COM using the cross-walk published by the UK's Occupational Information Unit (OIU, 2001). For the Swedish data, occupations were originally coded to NYK85 scheme then translated to ISCO-88 using algorithms generated by Bihagen. Electronic files documenting both algorithms are available for download from the GEODE portal (www.geode.stir.ac.uk).

iii Individuals are coded if their parents' occupation met the criteria for inclusion within the category rather than their actual position. Therefore, the Güveli measure for 'attended advantaged school if parent was advantaged' represents the percentage of people who attended such an institution amongst those whose parents held an advantaged Güveli occupational role. Therefore, this category refers to a different sample than the other rows in this table. It has been included for illustrative purposes and not used in any later regression analysis.

${ }^{\text {iv }}$ Similarly, this refers to the percentage of people who possess a degree amongst people whose parents would have met the inclusion criteria for the occupational grouping. This differs to the sample members identified in such a role, but will correspond to the 'attended advantaged school if parent was advantaged' category mentioned above.

${ }^{v}$ This data, like 8 , omits those people who have been identified as advantaged from their previous occupations, but their current occupational status is missing or unknown.
} 